\title{
Season of fire manipulates bud bank dynamics in northern mixed-grass prairie
}

\author{
Morgan L. Russell • Lance T. Vermeire • \\ Amy C. Ganguli • \\ John R. Hendrickson
}

Received: 20 January 2015/ Accepted: 4 April 2015/Published online: 14 April 2015

(C) The Author(s) 2015. This article is published with open access at Springerlink.com

\begin{abstract}
In perennial grassland dominated systems, belowground bud banks regulate plant community dynamics. Plant community responses to disturbance are largely driven by the ability to generate future aboveground growth originating from belowground axillary buds. This study examined bud bank dynamics for Bouteloua gracilis, Hesperostipa comata, and Pascopyrum smithii following fire in northwestern mixed-grass prairie in eastern Montana, USA. Belowground axillary buds were counted and classified for three growing seasons to determine immediate and short-term effects of summer, fall, and spring prescribed burns on patterns of bud bank activity, dormancy, and mortality. Prescribed burns did not
\end{abstract}

Communicated by Devan Allen McGranahan.

M. L. Russell ( $\square)$

Texas A\&M AgriLife Extension Service, 7887 US

Highway 87 North, San Angelo, TX 76901, USA

e-mail: morgan.russell@ag.tamu.edu

L. T. Vermeire

Fort Keogh Livestock and Range Research Laboratory, USDA-ARS, 243 Fort Keogh Rd, Miles City, MT 59301, USA

\section{A. C. Ganguli}

Department of Animal and Range Sciences, New Mexico State University, Las Cruces, NM 88003, USA

J. R. Hendrickson

Northern Great Plains Research Laboratory, USDA-ARS, P.O. Box 459, Mandan, ND 58554, USA result in immediate mortality of $B$. gracilis, $H$. comata, or $P$. smithii buds. Surprisingly, spring prescribed burns immediately increased the number of active $B$. gracilis buds. Summer fire, however, reduced $B$. gracilis active bud numbers. Fall burns immediately activated $P$. smithii buds, whereas fire did not influence any immediate bud dynamics for $H$. comata. Reduced bud numbers of $H$. comata may limit the ability to respond to fire. Season of fire directly manipulated bud activity, dormancy, and mortality for these species throughout the growing and dormant seasons following fire. Using season of fire to manipulate bud bank dynamics illustrates potential to improve post-fire management strategies based on known bud development trajectories and bud dynamics following fire.

Keywords Axillary bud · Dormancy · Grassland · Meristem limitation · Prescribed burn · Tiller

\section{Introduction}

The below ground population of axillary buds is a crucial driver of aboveground growth and persistence of grassland plant communities. More than $99 \%$ of new tiller growth originates from belowground vegetative bud banks and less than $1 \%$ from seed in some grasslands (Benson and Hartnett 2006). Although allocation of reproductive effort varies among ecosystems (Hartnett et al. 2006), dependence 
on bud banks may be expected for perennial grasslands world-wide, unless plants are very short-lived. Since bud banks are the source for future tiller growth, the size of a species' bud bank plays a decisive role in species and plant community response following disturbances, such as fire, grazing, and drought (Benson et al. 2004; Dalgleish and Hartnett 2009; Carter et al. 2012).

Almost all plant species produce and maintain vegetative buds belowground, aboveground, or both (Klimešová and Klimeš 2007). But, the size of the bud bank can vary both within and among species, and plant communities (Lehtila 2000). Tiller recruitment can be meristem limited, when there are not enough buds to completely replace the aboveground tiller population, constraining primary production (Dalgleish and Hartnett 2006). Although vegetative production is the primary source of new growth, bud densities can become limited or depleted if aboveground disturbances become too frequent, or occur during susceptible growth periods (Benson et al. 2004; Dalgleish and Hartnett 2009). These bud limitations may have consequences for aboveground growth if the timing of disturbance, such as fire and grazing, interferes with critical phenological growth patterns of buds further inhibiting the production or maintenance of belowground buds (Carter et al. 2012; Ott and Hartnett 2012). Potential bud limitations or stored reserves regulate aboveground responses to fire and species-specific levels of adaptations to fire (Olson and Richards 1998; Rogers and Hartnett 2001; Dalgleish and Hartnett 2006; Klimešová and Klimeš 2007). Given the role fire has played in shaping grasslands, perennial native grasses that evolved with frequent fire would be expected to be very efficient at maintaining bud reserves and subsequent tiller recruitment. Bud strategies of tiller recruitment and patterns of dormancy and viability of perennial native grasses involve different seasonal contributions of the bud bank. These seasonal fluxes include bud population growth rates, periods of bud sensitivity and dormancy, and potential responses to pulses of high resource availability or prolonged periods of stress (Towne and Owensby 1984).

Manipulating bud bank densities of native perennial grasses with fire may further reveal differences between bud bank dynamics of $\mathrm{a}_{3}$ and $\mathrm{C}_{4}$ grass. In tallgrass prairie, $\mathrm{C}_{4}$ species Andropogon gerardii maintained a larger dormant bud bank with longer- living buds compared to Dichanthelium oligosanthes, $\mathrm{a} \mathrm{C}_{3}$ species, that relied heavily on annual replacement with new buds and very little on dormant, reserve buds (Ott and Hartnett 2012). The bud phenologies of these two species differ dramatically from one another, with $\mathrm{C}_{4}$ species allowing buds to over-winter and recruit new spring tillers from pre-existing buds, and $\mathrm{C}_{3}$ species producing new active buds for the beginning of the growing season. These findings in tallgrass prairie illustrate differences in bud bank age structure, phenology, and dynamics (Ott and Hartnett 2012). Therefore, differences in bud strategy may afford some species an inherent buffering potential against timing of disturbance.

Seasonal timing of fire may reinforce bud transitions dictated by differing photosynthetic pathways. Bud transitions and tiller recruitment are inherently linked to a species' aboveground growth phenology based on photosynthetic pathways (Ott and Hartnett 2012). Therefore, aboveground production shifts due to seasonal prescribed burns may reflect possible timing differences in belowground recruitment from the bud bank (Steuter 1987; Ott and Hartnett 2012). Greater than $70 \%$ of wildfires in the western United States occur during summer, whereas most prescribed fires are conducted during spring and fall (Higgins 1984; Westerling et al. 2003; Vermeire et al. 2011). Using different seasons of fire may accelerate bud bank transitions for increased tiller recruitment from certain species, illustrating the mechanism responsible for aboveground production shifts. Furthermore, using bud banks as a quantifiable response to different seasons of fire may reveal the belowground mechanisms underlying potential plant community shifts with variously timed disturbances.

This study examined bud production and bud bank dynamics of three native perennial grass species with contrasting photosynthetic pathways and growth forms in mixed-grass prairie. The objectives of this study were to (1) assess immediate bud mortality of the $\mathrm{C}_{4}$ grass Bouteloua gracilis, the $\mathrm{C}_{3}$ caespitose grass Hesperostipa comata, and the $\mathrm{C}_{3}$ rhizomatous grass Pascopyrum smithii following summer, fall, or spring prescribed burns; (2) compare active and dormant bud abundance following summer, fall, or spring prescribed burns for each species; and (3) determine the short-term seasonal fluxes in bud dormancy, bud activity, and bud mortality following summer, fall, or spring prescribed burns. 


\section{Materials and methods}

\section{Site description}

Research was conducted at the USDA-ARS Fort Keogh Livestock and Range Research Laboratory in eastern Montana near Miles City, USA (lat $46^{\circ} 24^{\prime} \mathrm{N}$, long $\left.105^{\circ} 56^{\prime} \mathrm{W}\right)$. This site is mixed-grass prairie located in the Palouse Dry Steppe Province of the Great Plains and has a semi-arid climate at $815 \mathrm{~m}$ elevation. Annual precipitation averages $339 \mathrm{~mm}$, with a majority occurring from mid-April to midSeptember. Average daily temperatures range from $23{ }^{\circ} \mathrm{C}$ in July to $-8{ }^{\circ} \mathrm{C}$ in January and the frost-free growing season generally ranges from 125 to 150 days (Western Regional Climate Center 2013).

The research area was previously burned during the late summer of 2007 and heavily grazed in 2008, leaving approximately $300 \mathrm{~kg} \mathrm{ha}^{-1}$ of remaining herbaceous stubble (Waterman and Vermeire 2011). After 2008, the study area was excluded from livestock grazing. Topography of the site is flat with minimal slopes (0-4\%) and characterized as upland plains. The study site is dominated by Pinehill loams (fine, smectitic, frigid Aridic Haplustalfs) including a complex of Kobase clay loams (fine, smectitic, frigid Torrertic Haplustepts) and Gerdrum clay loams (fine, smectitic, frigid Torrertic Natrustalfs). The vegetation is dominated by perennial, native $\mathrm{C}_{3}$ species including, H. comata, $P$. smithii, and Carex filifolia and $\mathrm{C}_{4}$ species B. gracilis, and to a lesser extent, Bouteloua dactyloides. Annual grasses include Vulpia octoflora, Bromus arvensis, and Bromus tectorum. The primary shrub species on the site is Artemisia tridentata ssp. wyomingensis. Common forbs include perennial legume, Pediomelum argophyllum, and biennial forb, Tragopogon dubius. Plant nomenclature follows the USDA PLANTS database (USDA 2013).

Experimental design and fire measurements

Fire treatments were arranged in a completely randomized design with four fire treatments (summer, fall, spring, and no fire) and four replications applied to 16 , $20 \times 20$-m plots. Alleyways between plots were 3-m. Fuel load at the study site was approximately $1500 \mathrm{~kg} \mathrm{ha}^{-1}$ and all fires were set using the ring-fire method (Wright and Bailey 1982). Summer fires were applied following quiescence of $H$. comata and $P$. smithii plants. We applied summer fire on 7 September 2011 with ambient temperatures $20-26{ }^{\circ} \mathrm{C}$, winds $7-10 \mathrm{~km} \mathrm{~h}^{-1}$, and relative humidity $30-36 \%$. Fall fires were applied 3 November 2011, after the first killing frost, with ambient temperatures $8-11{ }^{\circ} \mathrm{C}$, winds $8-12 \mathrm{~km} \mathrm{~h}^{-1}$, and relative humidity $37-41 \%$. Lastly, spring fires were applied 29 March 2012 during late emergence phenological stage of $\mathrm{C}_{3}$ plant species with ambient temperatures $15-18{ }^{\circ} \mathrm{C}$, winds $13-20 \mathrm{~km} \mathrm{~h}^{-1}$, and relative humidity $39-43 \%$.

We utilized HOBO ${ }^{\circledR} \mathrm{U} 12 \mathrm{~J}, \mathrm{~K}, \mathrm{~S}, \mathrm{~T}$ Thermocouple Data Loggers (Onset Computer Corporation, Bourne, MA) with K-type Thermocouples (Omega Engineering, Inc., Stanford, CT) to create time-temperature profiles at the plot level (Table 1). We randomly placed thermocouples at the base of a perennial grass (1-2 cm above the soil surface) to quantify fire behavior at the plot level. Thermocouples were also placed within a $10 \times 10-\mathrm{m}$ square in the center of the plot (4 thermocouples plot $^{-1}$ ) to avoid edge effects. We programed the data loggers to record temperatures at one-second intervals. Maximum temperature was identified by finding the greatest value for each timetemperature profile. Heat duration was calculated as time (s) of heat greater than $60{ }^{\circ} \mathrm{C}$ and heat dosage was the sum of the degrees $>60{ }^{\circ} \mathrm{C}$ for the duration of elevated temperatures (degree-seconds). We used these measurements to derive the mean maximum temperature, heat duration, and heat dosage at the plot level.

Field and laboratory methods

Plant density was measured at the end of the growing seasons for 2011, 2012, and 2013 by counting individual plants rooted within a $0.25-\mathrm{m}^{2}$ quadrat centered on randomly selected target plants, with three quadrats per species in each plot. B. gracilis was considered an individual when gaps of $3 \mathrm{~cm}$ (Hendrickson et al. 2000) or greater were separating neighboring $B$. gracilis individuals. $P$. smithii plant density measurements were based on number of tillers per $0.25-\mathrm{m}^{2}$ quadrat. Individuals of $H$. comata were readily distinguished due to their bunchgrass growth form.

Tiller counts and plant density measurements were conducted simultaneously. Tillers were counted for four permanently marked plants per species and plot and classified as vegetative or reproductive. Definitions 
Table 1 Thermocouple observations at the plot level for summer and fall prescribed fires near Miles City, MT

\begin{tabular}{lcrr}
\hline Thermocouple measurements $^{\mathrm{a}}$ & Mean \pm SE & Maximum & Minimum \\
\hline Summer fire & & & 216 \\
$\quad$ Maximum temperature (C) & $172 \pm 15$ & 147 & 67 \\
Heat duration (s) & $110 \pm 20$ & 8193 & 5366 \\
Heat dosage (C s) & $6287 \pm 663$ & & 453 \\
Fall fire & & 270 & 435 \\
Maximum temperature (C) & $213 \pm 30$ & 17,601 & 43 \\
Heat duration (s) & $135 \pm 16$ & & 4589 \\
Heat dosage (C s) & $6336 \pm 1443$ & 399 & 417 \\
Spring fire & & 270 & 1861 \\
Maximum temperature (C) & $253 \pm 24$ & 13,707 & \\
Heat duration (s) & $135 \pm 16$ & \\
Heat dosage (C s) & $7801 \pm 961$ & & \\
\hline
\end{tabular}

$n=16$ for summer, fall, and spring fire

${ }^{\text {a }}$ Heat duration and dosage of heat were assessed using $60{ }^{\circ} \mathrm{C}$ as a base temperature. Heat duration was calculated as time (s) of heat $>60{ }^{\circ} \mathrm{C}$, and heat dosage was the sum of the degrees $>60{ }^{\circ} \mathrm{C}$ for each second (degree-seconds)

of an individual followed the same rules outlined for plant density measurements. Tiller counts for $P$. smithii were conducted within a $0.25-\mathrm{m}^{2}$ quadrat and results for $P$. smithii tiller counts were reported as tillers per $0.25-$ $\mathrm{m}^{2}$ quadrat instead of per individual plant.

Tillers were harvested from two individuals of each grass species for immediate and seasonal bud assessments. Tillers were harvested from two randomly determined individuals 12-24 h before prescribed burn treatments. Within 12-24 h after prescribed burn treatments, tillers were harvested from two randomly chosen individuals (pre- and post-burn individuals were different) to determine immediate bud mortality or activation. More specifically, tillers used for immediate bud assessments were harvested on 7 and 8 September 2011 (summer burns), 3 and 4 November 2011 (fall burns), and 29 March 2012 (spring burns). In order to address seasonal fluctuations for each species' bud bank, two individuals for each species were sampled on each plot throughout 2 years (30 July 2011, 15 March 2012, 21 July 2012, 4 November 2012, 25 January 2013, 24 February 2012, 27 March 2013, 5 May 2013, and 21 July 2013).

Buds were counted using a dissecting microscope. Bud activity (i.e., active buds, dormant buds, and dead buds) was confirmed using Tetrazolium and Evans Blue staining procedures (Busso et al. 1989; Hendrickson and Briske 1997). Tillers were submerged in Tetrazolium solution at room temperature for $24 \mathrm{~h}$ following initial classification. Active buds stained pink and dormant and dead buds retained a white or yellowish color. If non-stained buds were present on a tiller, that the tiller was submerged into Evan's Blue solution at room temperature following the tetrazolium staining for $20 \mathrm{~min}$. Upon completion of Evan's Blue staining, dormant buds maintained white pigment, whereas, dead buds stained dark blue.

\section{Statistical analysis}

Data were analyzed by species using analysis of variance (MIXED procedure of SAS, Littell et al. 2006) in order to quantify bud bank response immediately before and after summer, fall, and spring prescribed burns compared to non-burned plots. The model included burn treatment (fire, no fire) and season of prescribed burning (summer, fall, spring) and their interactions as fixed effects with plots as a random effect. Active, dormant, and dead buds were used as response variables, and the experimental unit was plot.

Data were collected prior to fire treatments and throughout one and two post-fire growing seasons to determine bud dynamics and plant community response. These data were analyzed using analysis of variance (MIXED procedure of SAS, Littell et al. 2006) with tiller harvest date as a repeated measure. The model included tiller harvest date and season of 
fire and their interactions as fixed effects for bud bank dynamics.

For aboveground dynamics, the model included year, fire, and their interactions as fixed effects. Response variables consisted of plant density, vegetative tillers, and flowering tillers. Pre-treatment data taken from 2011 were utilized as a covariate. If pre-treatment measurements were not significant $(P>0.05)$, they were eliminated from the model. We set statistical significance at $\alpha=0.05$ for all models.

\section{Results}

Growing conditions prior to the start of treatments in 2011 (April-June) were extremely wet, with record (226\% of average) spring precipitation (Fig. 1). The following winter, spring, and summer were $40 \%$ below average precipitation (Fig. 1). Spring 2012 was the second driest on record and drought conditions persisted throughout eastern MT and the northern Great Plains (Western Regional Climate Center, Reno, NV Western Regional Climate Center 2013). Spring of 2013 (two growing seasons following fire) was $63 \%$ greater than average, and summer precipitation was $17 \%$ greater than average, enabling growth of cool- and warm-season grasses following severe drought of 2011-2012.

\section{Bouteloua gracilis dynamics}

Plant density was similar across fire treatments $(P=0.15$; Table 2$)$ and between 2012 and 2013 (33

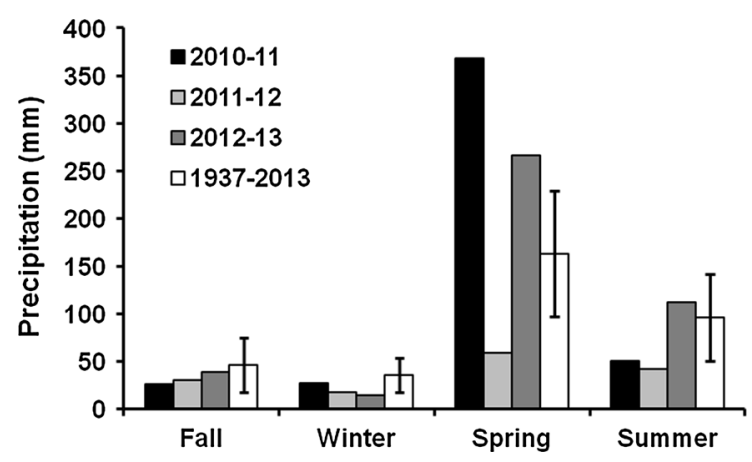

Fig. 1 Fall (Oct-Dec), winter (Jan-Mar), spring (Apr-Jun), and summer (Jul-Sep) precipitation for each study water year (Oct-Sep) and 76-year mean $( \pm \mathrm{SD})$ seasonal precipitation near Miles City, MT
Table 2 Plant density by species and fire treatment averaged across one and 2 years after fire near Miles City, MT

\begin{tabular}{llll}
\hline Fire treatment & $\begin{array}{l}\text { B. } \text { gracilis }^{\text {Plants m }}{ }^{-2} \\
\end{array}$ & H. comata & P. smithii \\
\hline Non-burned & 22 & 20 & 45 \\
Summer fire & 25 & 14 & 58 \\
Fall fire & 35 & 15 & 54 \\
Spring fire & 45 & 14 & 42 \\
SEM & 8 & 3 & 8 \\
\hline
\end{tabular}

vs $31 \pm 5$ plants $\left.\mathrm{m}^{-2} ; P=0.77\right)$. Vegetative tillers nearly doubled the second post-fire growing season (50 vs $25 \pm 4$ tiller plant $^{-1} ; P<0.01$ ), but were similar across fire treatments $(P=0.73)$ compared to non-burned plots. Reproductive tillers varied by the interacting effects of year and season of fire $(P<0.01)$. Reproductive tillers during 2012 were similar regardless of the season of fire treatment $\left(<1 \pm 1\right.$ tiller plant $\left.^{-1}\right)$; however, during 2013 reproductive tillers increased following summer, fall, and spring burns $\left(17,20,16 \pm 1\right.$ tiller plant ${ }^{-1}$, respectively) compared to non-burned plots $(7 \pm 1$ tiller plant $^{-1}$ ).

Bud mortality did not occur immediately following fire in any season $(P=0.41$; Table 3$)$. Short-term changes in bud mortality due to season were minimal throughout the two post-fire growing seasons $(P=0.15)$ and, overall, the number of dead buds was very low. Dead buds were most abundant during late winter $(P<0.01)$. Dead buds typically peaked during the winter following all prescribed burn treatments. The number of dead buds following fire was statistically different throughout the next two years; however, dead buds tiller $^{-1}$ never exceeded 0.25 and often were less than 0.01 buds tiller $^{-1}$. Surprisingly, bud mortality was similar between dry and wet years. Active bud development was nearly 3.5-fold greater immediately following spring burns compared to fall and summer fires, resulting in fewer dormant buds following spring fires $(P<0.01)$. In contrast to spring burns, summer fire immediately decreased active buds $36 \%(P<0.01)$. Consequently, dormant buds increased immediately following summer fire $(P<0.01)$. Fall fire did not affect active or dormant buds $(P>0.05)$.

Season of fire affected active bud bank dynamics differently during the two growing seasons following fire $(P<0.01$; Fig. 2). Summer burns resulted in more 
Table 3 Immediate $(<24 \mathrm{~h})$ summer, fall, and spring fire effects on active, dormant, and dead axillary bud means belonging to $B$. gracilis, $H$. comata, and $P$. smithii tillers near Miles City, MT

Means within bud classification and season of fire are similar when followed by a common letter $(P>0.05)$

Fig. 2 Bud dynamics of $B$. gracilis from July 2011 to July 2013 following no fire, summer, fall, and spring prescribed fire near Miles City, MT on B. gracilis a active buds tiller ${ }^{-1}$ $(P<0.01)( \pm$ SEM $)$ and b dormant buds tiller ${ }^{-1}$ $(P<0.01)( \pm$ SEM $)$

\begin{tabular}{|c|c|c|c|c|c|c|c|c|}
\hline \multirow[t]{2}{*}{ Measurement } & \multicolumn{2}{|l|}{ Summer } & \multicolumn{2}{|l|}{ Fall } & \multicolumn{2}{|l|}{ Spring } & \multirow[t]{2}{*}{ SEM } & \multirow[t]{2}{*}{$P$ value } \\
\hline & $\begin{array}{l}\text { No fire } \\
\text { Buds tiller }\end{array}$ & Fire & No fire & Fire & No fire & Fire & & \\
\hline \multicolumn{9}{|l|}{ B. gracilis } \\
\hline Active & $3.9 \mathrm{a}$ & $2.5 b$ & 4.9 & 4.3 & $2.4 \mathrm{~b}$ & $8.3 \mathrm{a}$ & 0.7 & $<0.01$ \\
\hline Dormant & $0.3 b$ & $1.1 \mathrm{a}$ & 0.3 & 0.3 & $1.5 \mathrm{a}$ & $0.3 b$ & 0.3 & 0.01 \\
\hline Dead & 0.0 & 0.0 & 0.0 & 0.3 & 0.0 & 0.0 & 0.1 & 0.41 \\
\hline \multicolumn{9}{|l|}{ H. comata } \\
\hline Active & 1.4 & 1.0 & 1.1 & 1.4 & 4.3 & 3.9 & 0.3 & 0.43 \\
\hline Dormant & 0.0 & 0.4 & 0.4 & 0.8 & 0.0 & 0.0 & 0.2 & 0.55 \\
\hline Dead & 0.1 & 0.4 & 0.1 & 0.3 & 0.4 & 0.3 & 0.2 & 0.56 \\
\hline \multicolumn{9}{|l|}{ P. smithii } \\
\hline Active & 3.4 & 2.9 & $3.6 b$ & $5.8 \mathrm{a}$ & 3.9 & 3.8 & 0.5 & 0.05 \\
\hline Dormant & 0.0 & 0.3 & 0.3 & 0.3 & 0.0 & 0.1 & 0.1 & 0.57 \\
\hline Dead & 0.0 & 0.4 & 0.3 & 0.1 & 0.3 & 0.3 & 0.2 & 0.43 \\
\hline
\end{tabular}
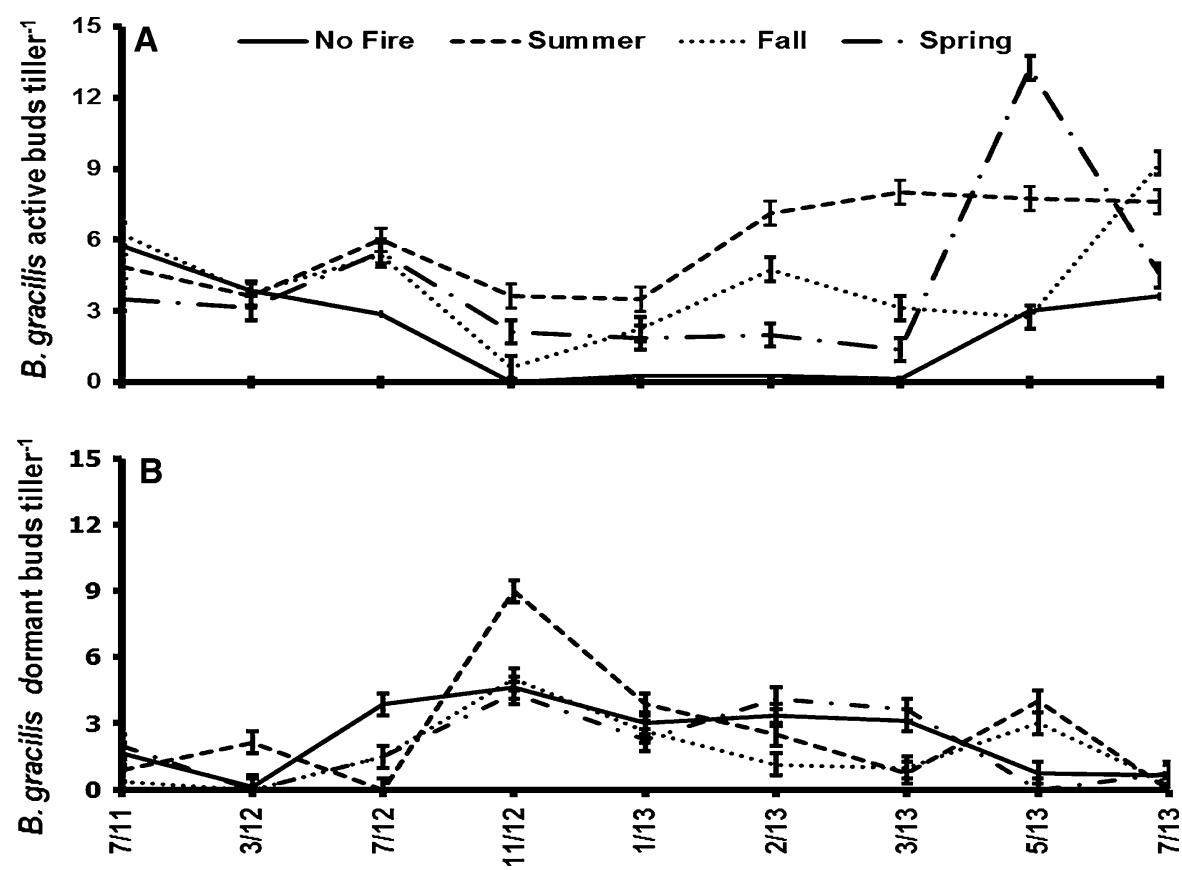

active buds than fall or spring-burned plots throughout winter $(P<0.01)$. Fall burns tripled new active buds by the end of the second post-fire growing season compared to non-burned plots $(P<0.01)$. Spring burns increased active buds at the beginning of the second post-fire growing season compared to nonburned plots and by then all buds were active $(P<0.01)$. Summer, fall, and spring burning increased active buds compared to non-burned plots during the drought of the first post-fire growing season (6.0, 5.4 and 5.5 vs $2.3 \pm 0.6$ buds tiller $^{-1} ; P<0.01$ ).

Dormant buds decreased the first growing season following summer, fall, and spring burns compared to non-burned plots $(P<0.01 ;$ Fig. 2$)$. Summer burned plots increased dormant buds entering the first winter after fire, whereas fall and spring burns were similar to non-burned plots $(P<0.01)$. At the initiation of the second post-fire growing season, dormant buds 
Fig. 3 Short-term bud dynamics of $H$. comata from July 2011 to July 2013 following no fire, summer, fall, and spring prescribed fire near Miles City, MT, on H. comata a active buds tiller $^{-1}(P<0.01)( \pm$ SEM $)$, b dormant buds tiller ${ }^{-1}$ $(P<0.05)( \pm$ SEM $)$ and c dead buds tiller ${ }^{-1}$ $(P<0.05)( \pm$ SEM $)$
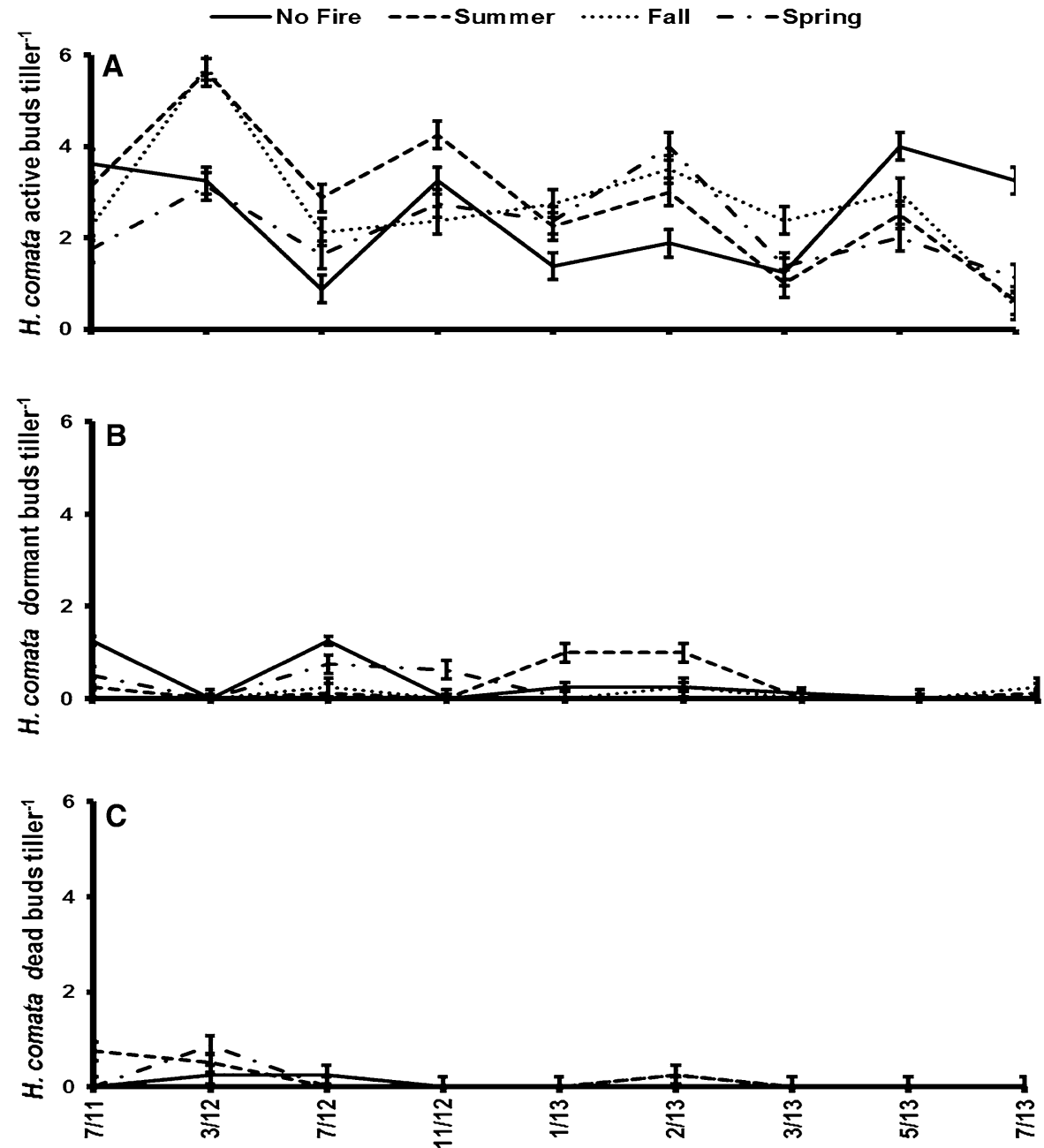

increased with summer and fall burns $(P<0.01)$. Dormant buds transitioned into active buds during May of the second growing season after spring fire and two months later after summer fire. The number of dead buds was similar among fire treatments $(P=0.15)$. There was always $<1$ dead bud tiller ${ }^{-1}$, but the number of dead buds was greatest during late winter $(P=0.01)$.

\section{Hesperostipa comata dynamics}

Plant density was similar among fire treatments $(P=0.50$; Table 2$)$. In addition, density estimates did not differ between the subsequent two post-fire growing seasons (16 and $15 \pm 2$ plants $\mathrm{m}^{-2}$; $P=0.83)$. Both vegetative and reproductive tiller numbers were similar among fire treatments, but each differed between post-fire study years $(P<0.01)$. Vegetative tillers increased from 15 to $33 \pm 3$ tillers plant $^{-1}$ and reproductive tillers increased from 0.2 to $5 \pm 1$ tillers plant $^{-1}$ between 2012 and 2013 $(P<0.05)$. . Fire had little effect on vegetative or reproductive tillers, regardless of the season in which it occurred ( $P=0.46$ and 0.60 , respectively).

Hesperostipa comata bud activity was not immediately impacted by fire $(P=0.43$ and 0.55 ; respectively; Table 3$)$. Fire also had no immediate effect on bud mortality regardless of season $(P=0.56)$. Despite the lack of immediate fire effects, season of fire played a key role in active bud dynamics throughout two growing seasons after fire (Fig. 3a). At the end of the first growing season, summer burns increased active buds compared to fall and spring burns and nonburned plots $(P<0.01)$. At the end of the second 
Fig. 4 Active buds tiller ${ }^{-1}$ $(P<0.01)$ for $P$. smithii from July 2011 to July 2013 following no fire, summer, fall, and spring prescribed fire active buds tiller ${ }^{-1}$ near Miles City, MT ( \pm SEM)

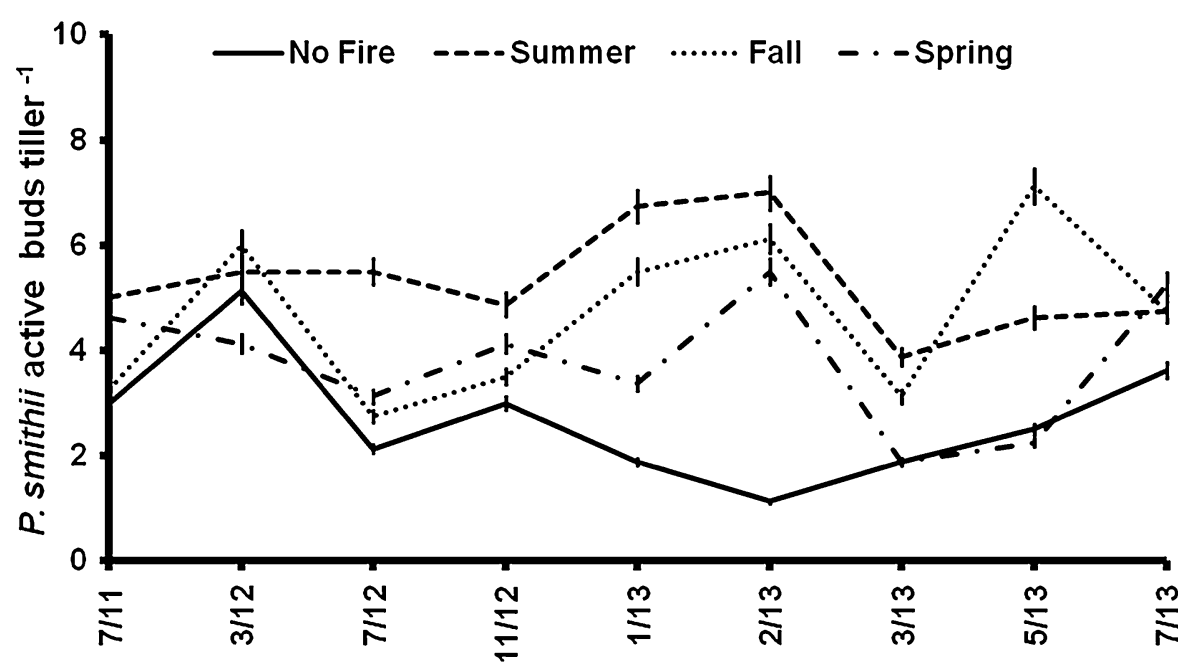

winter (February 2013), active buds were more abundant following fall and spring burns compared to summer burns and non-burned plots $(P<0.01)$. Active buds were reduced entering the second post-fire growing season by summer and spring burns $(P<0.01)$. These fire effects continued throughout the second growing season for summer, fall and spring burns, with 81,85 and $65 \%$ reductions, respectively.

Dormant buds were minimal, but varied between winter and growing seasons depending on the season of fire $(P<0.05$; Fig. 3b). Dormant buds were not present on $H$. comata tillers during winter of the first year following all seasons of fire. The following July, dormant buds increased for spring burns and nonburned plots. During the winter of the second year, dormant buds increased following summer burns compared to all other seasons of fire, including nonburned plots $(P<0.05$; Fig. $3 \mathrm{~b})$. However, similar dormant bud densities were maintained among all treatments $(P=0.18)$ at the start of the second growing season. Mortality of buds occurred only during the beginning of the first growing season following spring burns $(P<0.05$; Fig. $3 c)$. Spring burns increased dead buds compared to fall burns and non-burned plots during March 2012. No bud mortality was observed at the conclusion of the first and second growing seasons $(P=0.12)$.

Pascopyrum smithii dynamics

Plant density was similar among fire treatments $(P=0.53$; Table 2$)$ and did not differ between one and two post-fire growing seasons (58 and $42 \pm 6$ plants $\left.\mathrm{m}^{-2} ; P=0.07\right)$. Summer and fall fire increased vegetative tillers $\left(15 \pm 2\right.$ tillers $0.25 \mathrm{~m}^{-2}$ for each; $P=0.04)$ relative to non-burned plots $(9 \pm 2$ tillers $0.25 \mathrm{~m}^{-2}$ ). Tiller counts following spring fire were intermediate and similar to all fire treatments $(12 \pm 2$ tillers $\left.0.25 \mathrm{~m}^{-2}\right)$. Year and season of fire had interacting effects on reproductive tillers $(P=0.03)$. Reproductive tillers abundance was $<1$ tiller $0.25 \mathrm{~m}^{-2}$ and similar among all seasons of fire treatment during the first post-fire growing season. However, during the second post-fire growing-season reproductive tillers increased following summer and fall fires ( 8 and $7 \pm 1$ tillers $0.25 \mathrm{~m}^{-2}$ ) compared to spring-burned and nonburned plots ( 2 and $1 \pm 1$ tillers $0.25 \mathrm{~m}^{-2}$ ).

Summer, fall, and spring fire had no immediate effect on dormant or dead buds for $P$. smithii ( $P=0.57$ and 0.43 , respectively; Table 3 ). However, development of active buds increased $61 \%$ immediately following fall fire $(P<0.05)$. Development of active buds primarily occurred during the second year following fire $(P<0.01$; Fig. 4). Active, overwintering buds increased following summer and fall fire compared to spring burns and non-burned plots $(P<0.01)$. Increased activity of buds continued through the winter for summer, fall, and spring burns compared to non-burned plots $(P<0.01)$. By the beginning of the second post-fire growing season, only fall and summer fires increased bud activity $(P<0.01)$, and active bud counts became similar across all fire treatments by the middle of the second growing season $(P=0.25)$. 
Maintenance of dormant buds differed among fire treatments $(P<0.05)$ and over time $(P<0.01)$. Generally, dormant buds were reduced by summer, fall, and spring fires $(0.7,0.5$, and $0.9 \pm 0.2$ buds tiller $\left.^{-1}\right)$ compared to non-burned plots $(1.5 \pm 0.2$ buds tiller ${ }^{-1}$ ). Dormant buds were most abundant during July and November of the first growing season and February 2013 (1.5, 1.6 and $1.5 \pm 0.3$ buds tiller $\left.^{-1}\right)$ and fewest during March $2012(0.2 \pm 0.3$ buds tiller $\left.{ }^{-1}\right)$, with no consistent seasonal pattern for maxima and minima $(P<0.01)$. Mortality of buds was relatively minor during the first post-fire growing season (March 0.5, July 0.1, November $0.4 \pm 0.1$ buds tiller $\left.{ }^{-1} ; P<0.01\right)$. However, bud mortality increased $(P<0.01)$ during initiation of the second growing season (March 1.2 and May $1.1 \pm 0.1$ buds tiller $\left.^{-1}\right)$ with no observed fire effects $(P=0.74)$.

\section{Discussion}

To determine the role of native perennial grass bud banks in mixed-grass prairie response to fire we assessed immediate bud mortality of B. gracilis, $H$. comata, and $P$. smithii following summer, fall, and spring prescribed burns. Prescribed burns did not result in immediate mortality of B. gracilis, H. comata, or $P$. smithii buds. As expected, results supported the overall premise that bud bank dynamics differ among these species. Active and dormant bud abundance following seasonal prescribed burns differed for each species and short-term seasonal fluxes in bud dormancy, bud activity, and bud mortality varied according to the season of burning.

\section{Aboveground dynamics}

Plant density was similar for the three species among all seasons of fire, including non-burned plants, and for 2 years following fire. Similar densities among summer, fall, and spring fire and non-burned controls combined with variable spring precipitation suggest that these native perennial grasses are well adapted to fire and spring drought (Russell et al. 2013). These responses are indicative of their evolutionary history and plant adaptations (Engle and Bultsma 1984; Umbanhowar 1996; Pausas and Schwilk 2012).

Bouteloua gracilis and $H$. comata tiller numbers decreased the first post-fire growing season, regardless of season of burning. Drought effects likely stunted vegetative and reproductive tiller emergence, especially for $\mathrm{C}_{3}$ species, since spring precipitation was $44 \%$ below the long-term (1937-2012) average during the first post-fire growing season. Spring precipitation is better than annual or growing season precipitation for predicting peak standing crop in eastern Montana (Vermeire et al. 2008; 2009; Wiles et al. 2011). Reductions in tillers during the first year following fire treatments are similar to responses in tallgrass prairie, where tillers were reduced by drought, but increased the following year because of bud bank recovery (Carter et al. 2012). By the second post-fire growing season both total and reproductive tillers more than doubled. Similar second year response following fire has been observed in northern mixed-grass prairie, where perennial grasses made a substantial recovery the second year following fire during drought conditions (Engle and Bultsma 1984; Vermeire et al. 2011).

Immediate season of fire effects on bud bank dynamics

Neither summer, fall, nor spring fire affected bud mortality for any species immediately after fire. Survival of species during a fire event usually depends on available vegetative buds to generate new growth (Dalgleish and Hartnett 2009). Belowground buds are well protected from direct effects of fire due to the buffering capacity of soil and soil moisture (Alexander 1982; Bradstock and Auld 1995). In contrast, aboveground vegetation is susceptible to fire and $1 \mathrm{~min}$ at a temperature of only $60{ }^{\circ} \mathrm{C}$ is, in most cases, sufficient to coagulate proteins and cause lethal damage to aboveground plant tissue (Precht et al. 1973). Both $B$. gracilis and $P$. smithii axillary bud resistance to fire stem from their geophyte growth form (Raunkiaer 1934). This type of growth form maintains underground storage organs, which helps the plant survive adverse environmental conditions such as drought or fire (Raunkiaer 1934).

Due to its bunchgrass growth form, $H$. comata may be more sensitive to fire due to the elevation of meristems into the crown of the plant as the growing season progresses (Ewing and Engle 1988). Bunchgrasses are generally more susceptible to fire damage because litter accumulates in the crown of these species over time, potentially increasing the fuel load and resulting in greater heat duration and heat dosage 
(Wright 1971; Wright and Bailey 1982; Engle et al. 1998). Bud mortality in bunchgrasses has been reported to be greater in the middle of the plant compared to the outer edges where litter accumulation is less (Morgan and Lunt 1999). Fire reduced axillary buds plant $^{-1} 25-70 \%$ for Aristida purpurea, a bunchgrass that is common throughout the Great Plains, but generally a minor component (Russell et al. 2013; Russell and Vermeire 2015). In contrast to previously observed fire responses of bunchgrasses, immediate bud mortality did not occur in this study for $H$. comata. This may be due to the dense bunch-form of $H$. comata, which may have extinguished the fire or decreased heat duration due to lack of oxygen at the crown. Some plants, like $H$. comata, protect vegetative buds through the sheath of the tiller, where top removal of fine fuels has minimal effects on wellprotected axillary buds that are just above the soil surface (Morgan and Lunt 1999). When a fire occurs in grasslands, it generally sweeps across the top of vegetation with minimal heat transfer to the base (Wright 1971). Due to H. comata's coarse stems and dense plant crown, the base of the plant may have been compacted adequately enough to prevent direct heat transfer to the buds (Haile 2011). Heat threshold conditions required to produce greater than 0.5 probability of mortality for $\mathrm{H}$. comata are $56,985{ }^{\circ} \mathrm{C}$ $\mathrm{s}, 10.4 \mathrm{~min}$ above $60{ }^{\circ} \mathrm{C}, 628^{\circ} \mathrm{C}$ maximum temperature, and $8500 \mathrm{~kg} \mathrm{ha}^{-1}$ fuel load (Haile 2011). The thresholds reported for $H$. comata are substantially greater than the fire intensities recorded for summer, fall, or spring fire treatments for this study.

Activity of $B$. gracilis buds increased immediately following spring fires. Additionally, fall fire immediately increased active bud development of $P$. smithii. Spring and fall fire served as catalysts for both species, stimulating new bud growth, transitioning dormant buds into active buds, and initiating buds into future tillers within $24 \mathrm{~h}$ of burning. Immediate active bud responses were not expected, but may be possible due to the removal of litter and existing vegetation (Wright and Bailey 1982) and evolutionary response (Towne and Owensby 1984).

Immediate bud bank responses to fire may also be due to temporary transitions in buds. In many cases, newly formed axillary buds enter transition stages of temporary growth or dormancy (Devitt and Stafstrom 1995; Shimizu and Mori 2001). Buds cycle through these temporary transition stages until a developmental or environmental cue signals buds to become fully dormant or undergo growth. The timing of spring fire most likely manipulated $\mathrm{C}_{4}$ buds during temporary transition periods and acted as an environmental signal for buds to enter active growth. Similarly, the timing of fall fire manipulated developing $\mathrm{C}_{3}$ buds to increase activity and growth. In contrast, summer fires decreased B. gracilis bud activity and increased bud dormancy. Axillary buds in temporary transitions can become developmentally arrested if an environmental cue signals heat or drought-induced quiescence. These dormant axillary buds resume development at a later time, depending on their developmental program, or in response to environmental cues (Stafstrom and Sussex 1992; Shimizu and Mori 1998). This temporary bud strategy is possible since northern mixed-grass prairie evolved under summer fire regimes where temporary dormancy of buds may be advantageous in order to cope with increased summer fire intensity and heat stress (Higgins 1984; Umbanhowar 1996).

Season of fire effects on short-term bud bank dynamics

Bouteloua gracilis bud banks were more active during drought if burned the previous year. Non-burned plants increased dormant buds compared to burned plants during summer drought. Bud bank activity of $B$. gracilis likely increased due to increased nitrogen availability following fire (Cui and Caldwell 1997; Enquist et al. 1998). Since B. gracilis total buds did not increase during drought conditions, it is likely that B. gracilis bud banks were able to recover by transitioning dormant buds into active buds, contributing to plant community persistence in challenging environments following drought and fire.

By the end of the study, $H$. comata had the smallest bud bank of all species and contained $73 \%$ fewer buds on burned plots compared to control plots. When species do not maintain a large population of belowground buds throughout the growing season, meristem limitations occur which limit the plants ability to respond to disturbance. Since bud production did not increase as tiller production increased, bud banks of $H$. comata were not replenished and plants became meristem limited. Depleted bud banks of $H$. comata also align with previous bud bank studies in tallgrass prairie that reported $\mathrm{C}_{3}$ species maintain a smaller bud bank with short-lived buds and tiller recruitment 
occurs from current year's buds only (Ott and Hartnett 2012). Therefore, in northern mixed-grass prairie, $H$. comata would be expected to closely track interannual environmental changes and demonstrate fluctuating bud populations and potential meristem limitations due to variable environmental conditions.

Unlike bud banks of $H$. comata, $P$. smithii, also a $\mathrm{C}_{3}$ grass, maintained a large overwintering reserve of dormant and active buds following summer and fall fires. New bud growth and increased bud activity for $P$. smithii during winter dormancy following spring, and summer fires are similar to this study's $\mathrm{C}_{4}$ bud bank results and $\mathrm{C}_{4}$ bud response in tallgrass prairie. For $\mathrm{C}_{4}$ species, young buds and older buds produced in previous years comprise the overwintering bud bank (Ott and Hartnett 2012). Similar to P. smithii bud bank results, overwintering bud banks of $\mathrm{C}_{4}$ species in tallgrass prairie remain active in order to rapidly transition into new tillers before warmer summer temperatures occur (Ott and Hartnett 2012).

\section{Conclusions}

Native, perennial grasses in mixed-grass prairie rely heavily on the maintenance of the bud bank to regenerate and persist in environments dominated by fire, drought, and herbivory, common characteristics of the northern Great Plains. Belowground bud banks respond positively by increasing bud activity and having minimal bud mortality following moderate fire intensity. Both B. gracilis and P. smithii responded to fire with increased bud activity throughout winter dormancy, replenishing bud bank reserves and capitalizing upon early spring resources (e.g., precipitation). This plant strategy is effective in northern mixed-grass prairie due to variation in precipitation patterns. Furthermore, summer, fall, and spring fires manipulated $\mathrm{C}_{3}$ and $\mathrm{C}_{4}$ grasses differently, illustrating the potential for flexible resource allocation and growth tradeoffs. Differences in species responses to season of fire can influence future patterns of reproduction and community dynamics of perennial grasses. Manipulating bud bank dynamics by season of fire illustrates potential to improve management strategies following wildfires or planning prescribed burns based on the trajectory of bud development. Incorporating knowledge of bud bank dynamics will also inevitably improve overall predictions of grassland vegetation response to fluctuating environmental growing conditions.

Open Access This article is distributed under the terms of the Creative Commons Attribution 4.0 International License (http:// creativecommons.org/licenses/by/4.0/), which permits unrestricted use, distribution, and reproduction in any medium, provided you give appropriate credit to the original author(s) and the source, provide a link to the Creative Commons license, and indicate if changes were made.

\section{References}

Alexander ME (1982) Calculating and interpreting forest fire intensities. Can J Bot 60:349-357

Benson EJ, Hartnett DC (2006) The role of seed and vegetative reproduction in plant recruitment and demography in tallgrass prairie. Plant Ecol 187:163-178

Benson EJ, Hartnett DC, Mann H (2004) Belowground bud banks and meristem limitation in tallgrass prairie plant populations. Am J Bot 91:416-421

Bradstock RA, Auld TD (1995) Soil temperatures during experimental brushfires in relation to fire intensity: consequences for legume germination and fire management in south-eastern Australia. J Appl Ecol 32:76-84

Busso CA, Mueller RJ, Richards JH (1989) Effects of drought and defoliation on bud viability in two caespitose grasses. Ann Bot 63:477-485

Carter DL, VanderWeide BL, Blair JM (2012) Drought-mediated stem and belowground bud dynamics in restored grasslands. Appl Veg Sci 15:470-478

Cui M, Caldwell MM (1997) Shading reduces exploitation of soil nitrate and phosphate by Agropyron desertorum and Artemisia tridentata from soils with patchy and uniform nutrient distribution. Oecologia 109:177-183

Dalgleish HJ, Hartnett DC (2006) Below-ground bud banks increase along a precipitation gradient of the North American Great Plains: a test of the meristem limitation hypothesis. New Phytol 171:81-89

Dalgleish HJ, Hartnett DC (2009) The effects of fire frequency and grazing on tallgrass prairie productivity and plant composition are mediated through bud bank demography. Plant Ecol 201:411-420

Devitt ML, Stafstrom JP (1995) Nucleotide sequence of four ribosomal protein L27 cDNAs from growing axillary buds of pea. Plant Phys 107:1031-1032

Engle DM, Bultsma PM (1984) Burning of northern mixedprairie during drought. J Range Manag 37:398-401

Engle DM, Mitchell RL, Stevens RL (1998) Late growingseason fire effects in mid-successional tallgrass prairies. J Range Manag 51:115-121

Enquist BG, Brown JH, West GB (1998) Allometric scaling of plant energetic and population density. Nature 395:163165

Ewing AL, Engle DM (1988) Effects of late summer fire on tallgrass prairie microclimate and community composition. Am Midl Nat 120:212-223

Haile KF (2011) Fuel load and heat effects on northern mixed prairie and four prominent rangeland graminoids. Thesis, Montana State University 
Hartnett DC, Setshogo MP, Dalgleish HJ (2006) Bud banks of perennial savanna grasses in Botswana. Afr J Ecol 44: 256-263

Hendrickson JR, Briske DD (1997) Axillary bud banks of two semiarid perennial grasses: occurrence, longevity, and contribution to population persistence. Oecologia 110:584591

Hendrickson JR, Moser LE, Reece PE (2000) Tiller recruitment patterns and biennial tiller production in prairie sandreed. J Range Manag 53:537-543

Higgins KF (1984) Lightening fires in North Dakota grasslands and in pine-savanna lands of South Dakota and Montana. J Range Manag 37:100-103

Klimešová J, Klimeš L (2007) Bud banks and their role in vegetative regeneration-A literature review and proposal for simple classification and assessment. Perspect Plant Ecol 8:115-129

Lehtila K (2000) Modeling compensatory regrowth with bud dormancy and gradual activation of buds. Evol Ecol 14:315-330

Littell RC, Milliken GA, Stroup WW, Wolfinger RD, Schabenberger O (2006) $\mathrm{SAS}^{\circledR}$ for mixed models, 2nd edn. SAS Institute Inc, Cary

Morgan JW, Lunt ID (1999) Effects of time-since-fire on tussock dynamics of a dominate grass (Themeda triandra) in a temperate Australian grassland. Biol Conserv 88:379-386

Olson BE, Richards JH (1998) Annual replacement of the tillers of Agropyron desertorum following grazing. Oecologia 76:1-6

Ott JP, Hartnett DC (2012) Contrasting bud bank dynamics of two co-occurring grasses in tallgrass prairie: implications for grassland dynamics. Plant Ecol 213:1437-1448

Pausas JG, Schwilk D (2012) Fire and plant evolution. New Phytol 193:301-303

Precht H, Christophersen J, Hensel H, Larcher W (1973) Temperature and life. Springer-Verlag, Heidelberg

Raunkiaer C (1934) The life forms of plants and statistical plant geography. Clarendon Press, London, p 632

Rogers WE, Hartnett DC (2001) Vegetation response to different spatial patterns of soil disturbances in burned and unburned tallgrass prairie. Plant Ecol 155:99-109

Russell ML, Vermeire LT (2015) Fire and nitrogen alter axillary bud number and activity in purple threeawn. Range Ecol Manag. doi:10.1016/j.rama.2014.12.009

Russell ML, Vermeire LT, Dufek NA, Strong DJ (2013) Fire, defoliation, and competing species alter Aristida purpurea biomass, tiller, and axillary bud production. Range Ecol Manag 66:290-296

Shimizu SS, Mori H (1998) Changes in protein interactions of cell cycle-related genes during the dormancy-to-growth transition in pea axillary buds. Plant Cell Phys 10:1073-1079

Shimizu SS, Mori H (2001) Control of outgrowth and dormancy in axillary buds. Plant Phys 127:1405-1413

Stafstrom JP, Sussex IM (1992) Expression of a ribosomal protein gene in axillary buds of pea seedlings. Plant Phys 100:1494-1502

Steuter AA (1987) $C_{3} / C_{4}$ composition shift on seasonal burns: northern mixed prairie. J Range Manag 40:27-31

Towne G, Owensby C (1984) Long-term effects of annual burning at different dates in ungrazed Kansas tallgrass prairie. J Range Manag 37:392-397

Umbanhowar CE Jr (1996) Recent fire history of the northern Great Plains. Am Midl Nat 135:115-121

USDA NRCS (2013) The PLANTS database. http://plants.usda. gov. Accessed 7 September 2013

Vermeire LT, Heitschmidt RK, Haferkamp MR (2008) Vegetation response to seven grazing treatments in the northern Great Plains. Agric, Ecosyst, Environ 127:66-72

Vermeire LT, Heitschmidt RK, Rinella MJ (2009) Primary productivity and precipitation use efficiency in mixedgrass prairie: a comparison of Northern and Southern U.S. Sites. Range Ecol Manag 62:230-239

Vermeire LT, Crowder JL, Wester DB (2011) Plant community and soil environment response to summer fire in the Northern Great Plains. Range Ecol Manag 64:37-46

Waterman RC, Vermeire LT (2011) Grazing deferment effects on forage diet quality and ewe performance following summer rangeland fire. Range Ecol Manag 64:18-27

Westerling AL, Gershunov A, Brown TJ, Cayan DR, Dettinger MD (2003) Climate and wildfire in the western United States. Bull Amer Meteorol Soc 84:595-604

Western Regional Climate Center (2013) Western U.S. climate historical summaries. http://www.wrcc.dri.edu/cgi-bin/ cliMAIN.pl?mt5690. Accessed 22 August 2013

Wiles LJ, Dunn G, Printz J, Patton B, Nyren A (2011) Spring precipitation as a predictor for peak standing crop of mixed-grass prairie. Range Ecol Manag 64:215-222

Wright HA (1971) Why squirreltail is more tolerant to burning than needle-and-thread. J Range Manag 24:277-284

Wright HA, Bailey AW (1982) Fire ecology: United States and southern Canada. Wiley, New York 